\title{
A STEAM ACTIVITY THAT CAN BE USED IN SCIENCE EDUCATION
}

\author{
Gülbin ÖZKAN ${ }^{1}$ \\ Ünsal UMDU TOPSAKAL ${ }^{2}$
}

1 Arş. Gör., Yıldız Teknik Üniversitesi, gozkan@yildiz.edu.tr, ORCID: 0000-0001-8390-5259

2 Prof. Dr., Y1ldız Teknik Üniversitesi, topsakal@yildiz.edu.tr, ORCID: 0000-0002-0565-7891

Özkan Gülbin ve Ünsal Umdu Topsakal. “A steam activity that can be used in science education” ulakbilge, 45 (2020 Şubat): s. $185-199$.

doi: 10.7816/ulakbilge-08-45-06

\begin{abstract}
In STEAM education the fields of science, mathematics, engineering, art and technology are taught by integrating these fields in a holistic way instead of teaching them separately. However, preparing STEAM activities that helps actualizing students' learning in terms of concepts, principles and actions related to science classes is a difficult process. This study involves a STEAM activity prepared as a sample that can be used in teaching and learning process. The activity prepared was implemented to $7^{\text {th }}$ grade middle school students composed of 37 participants. Before and after implementation, a questionnaire that was composed of three open ended questions was applied in order to determine how the activity is effective. As a result of the implementation, it was concluded that the activity developed was effective in students' learning in the science topic entitled as conservation of energy. For this reason, it is thought that the activity prepared about the conservation of energy topic in which students have a lot of misconceptions will be a useful class activity that can improve students' meaningful learning. Besides, it can also be used as a practical teaching design that can easily be used in crowded classes.
\end{abstract}

Keywords: STEM, STEAM, activity, energy, middle school students 


\section{Introduction}

Today, the need for the individuals who can think, produce, invent, question and think creatively in science, technology, engineering, arts and mathematics is increasingly growing. For this reason, in order to increase the number of people who work in these fields, we should re-structure teaching and learning processes. Having new and different approaches in education is the natural consequence of this situation.

STEM is an abbreviation made from the initials of science, technology, engineering and mathematics (Moomaw, 2013). The purpose of STEM education is to convert learning in a connected, focused, meaningful and relational form by connecting these disciplines into each other (Smith \& Karr-Kidwell, 2000). Social development is ensured by getting individuals to be entrepreneurs through STEM education and connections between school, society and working life are established. In addition to this, it is ensured for individuals to form connections between science, technology, engineering and mathematics fields and people use these connections in their everyday lives (Thomas, 2014).

While teaching science and mathematics, integrating engineering and technology into these fields is seen as important for the societies. Preparing teaching programs involving teaching multiple disciplines is necessary for raising individuals who have certain competencies (Ramaley, 2007).

Training qualified teachers and having them implement STEM-based activities can only be realized by using suitable programs. Teachers who have proper education and competencies in STEM field have a crucial role in implementing STEM education commonly and properly (Wang, 2012). For this reason, it is important to make necessary guidance to teachers which will allow them to plan the implementation phase and to develop new activities.

STEM education appeared in Korea (Yakman \& Lee, 2012) when it became prominent in America and Europe (Gonzalez \& Kuenzi, 2012). STEAM education is defined as an interdisciplinary approach after adding art into STEM education (Park \& Ko, 2012). STEAM education is developed to understand the nature of correlation among science, technology, engineering, art and mathematics.

\section{STEM Activities}

Mathematics and Science fields are taught as separate disciplines particularly in primary and secondary education. Integrating technology and sciences in schools is rarely or never employed (Öner \& Capraro, 2016). The activities carried out in teaching and learning programs, in classes and after school can ensure students to learn fields within the scope of STEM education and correlations among them (Guzey, Harwell \& Moore, 2014).

The studies carried out on STEM activities developed as design-based revealed that in addition to increasing academic achievement in science and mathematics, they help them gain technological literacy, increase their problem solving skills, improve their creativity, ensure them to communicate easily and to be able to think interdisciplinary (Douglas, Iversen, \& Kalyandurg, 2004; Ozkan \& Topsakal, 2017 ).

There are various positive effects of STEM education on students; however, the implementation process of STEM activities is not that easy. Specifically, the most important difficulty that teachers face is to combine STEM fields because STEM education requires an interdisciplinary approach. As the teachers are competent in only their own fields, they do not or may not have enough information about the other fields of STEM. This creates difficulties in terms of developing STEM activities. The attitudes and beliefs of teachers towards other fields also direct their teaching and learning process (Eroğlu \& Bektaş, 2016). For this reason, it is important to guide teachers to have an effective STEM education.

Instead of implementing STEM education with traditional teaching approaches, it should be implemented with teaching approaches which are open to innovation and which transfer everyday life problems to teaching settings and which provide students to develop projects (Breiner, Harkness, Johnson \& Koehler, 2012). It is necessary to ensure students' active participation to teaching process to achieve the objectives of the science teaching programs (Sağır \& Kılıç, 2013). While planning STEM activities, we should consider the objectives of the teaching programs.

STEM education focuses on the interdisciplinary co-operation and it is necessary to encourage students to work in a co-operative way (Aslan-Tutak, Akaygün \& Tezsezen, 2017). It is important to have group work while implementing STEM activities.

A qualified STEM education should encourage students to understand how tools and equipment work, to use 
technology, to make measurements and calculations during activities (Bybee, 2010).

The nature of science, mathematics, technology and engineering is similar to each other and it is necessary to design learning environments which are suitable to reflect their nature. These four fields are related to everyday life closely (Rockland et al., 2010). For this reason, STEM activities should not be isolated from everyday life and they should carry everyday life problems into learning environments.

\section{Current Study}

The main aim of the current study was to provide a STEAM activity for the seventh grade middle school students in Turkey and to determine its efficacy. The second aim of our study was to display an effective STEAM activity as an example for practitioners. Accordingly, this article describes the STEAM activity steps that were conducted with middle school students and its effects on students' understanding of conservation of energy concepts.

\section{Methodology}

This study contains improving a process about improving and implementing a STEAM activity. The process of the activity is explained step by step in order to assist teachers in teaching and learning process. The study was carried out in 2016-2017 academic years. The teaching was carried out by using an activity developed on topic related to the transformation of energy types. The length of the activity is four class hours. Worksheets were created to carry out the activity in a planned way and each worksheet was collected at the end of the activity and they were analysed one by one.

A questionnaire which was composed of three open ended questions was conducted in order to determine the effectiveness of the activity. The questions used in the questionnaire are as in the following: (1) How do you define energy? (2) Is energy used? Does it decrease or exhaust? (3) Can energy be transformed from one type to another? The responds provided for these questions were analysed by using content analysis to understand whether they differ before and after the implementation. The reason why data were not collected in a detailed and multidimensional way is the fact that the primary objective of the study is to develop an advisory activity and to explain the process of implementing this activity.

\section{The Study Group}

The study group of this study was determined by using purposeful sampling. The purposeful sampling enables us to study situations which are thought to have in-depth information in a detailed way (Yıldırım \& Şimşek, 2008, pp. 107). None of the students took STEAM or STEM education before the implementation.

37 seventh grade students from Istanbul, Turkey participated in the study. 16 of these students are female and 21 of them are male students. Consent forms are collected from all the participants and the study was carried out by considering ethical principles.

\section{Instrument Design}

In creating STEAM activity, STEAM design steps created by Oh, Lee and Kim (2013) were used. While reserachers were developing these steps, they used creative design steps stated by Korean Foundation for Advancement of Science and Creativity. These steps were implemented during STEAM education which was carrried out throug a computer software by Oh, Lee and Kim (2013). It was then adopted to this study and teaching within the scope of this study was carried out according to this plan. A worksheet was prepared in order to carry out teaching in a planned way. The worksheet was composed of six steps which are seperated acccording to Oh, Lee and Kim's (2013) steps.

The worksheet developed was given to a lecturer who works in STEM and STEAM fields and two science teachers in order to obtain the opinions of the experts on the worksheet. After the experts stated that the activity was understandable and suitable to the levels of the students, five students from the same age group read the activity. These students were asked whether there was something that they did not understand. In conclusion, it was determined that there was not any point in the activity confusing for the students and the final version of the activity was written. 
In order not to limit the creativity of the students, materials in various colours and types were obtained. Tools and equipment used in STEAM design process are the ones that one can easily buy from and supermarket or stationers.

\section{Implementation of STEAM Activity}

Before starting to teach, students were divided into nine groups. Each group consisted of four students but there are five students only in one group.

First of all, teaching was started by giving the worksheet to the students. The worksheet was given to the students individually. The students were asked to follow the instructions stated in this worksheet. After giving the worksheet to the students, it was asked from a volunteer student to read the problem situation loudly in the classroom. The reason of this is to engage all students into the activity and to ensure that steps are taken simultaneously. The teacher only guided in the whole design process of STEAM and did not intervene to the students. Students were provided to find the solution of the problem freely.

The learning outcomes of this activity which was used in the study are as in the following:

Science:

- Students explain the conservation of energy and deduce the fact that energy forms can transform from one type to another.

- Students explain the types of wind energy.

- Students conduct studies on energy transformation.

Mathematics:

- Students think in three dimension.

- Students create propeller blades evenly by making calculations.

Technology:

- Students do research by utilizing technology.

Art:

- Students present an original product.

- Students ensure that the design looks aesthetic.

- Students add aesthetic details to the design.

Engineering:

- Students establish reason and result relationship while creating their products.

- Students come up with a design.

- Students analyses a system or a process for determining needs.

- Students present solution methods and choose the optimum solution.

\section{$1^{\text {st }}$ STEP: Experiencing priming water for an idea}

At this step, students were given a problem situation including a scenario. By using this given scenario, students were expected to determine the problems and specify their objective to develop their products. A problem situation was constructed in the minds of the students through these scenarios. It was ensured for students to create ideas for the design that they will develop by taking their attention.

In figure 1, the part which was prepared for the first step of the worksheet was presented. 


\section{IT IS TIME TO PROVE ENERGY TRANSFORMATION}

\section{YOUR TASK}

The fact that hydroelectric power plants contaminates water resources and the risks of thermal and nuclear power plants to environment are getting increased have caused many reactions in your city. From now on, discussions have started on the necessity to use wind energy as an alternative. It was concluded that the conditions of our city was suitable to produce wind energy. You joined the project team who will construct wind turbine to use wind energy within the scope of sustainability project in your city.

Things to consider in your design:

-The design should be completed in the given time.

-The cost of the design should be low.

-Your design should be different and outstanding.

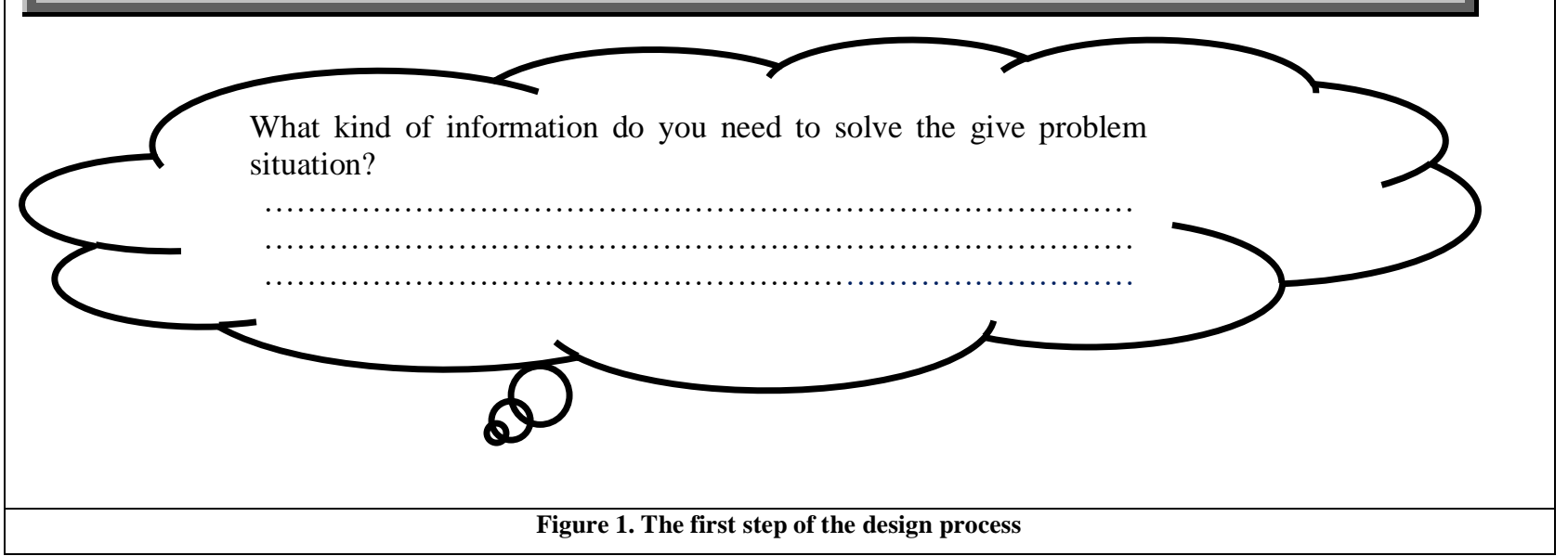

The following sentences and questions can be given as an examples of students' responses give at this step:

"I have to know the meaning of the wind energy." (Student 5)

"How we can use wind energy?" (Student 27)

"What are the parts of the windmill that you will construct to produce wind energy?" (Student 15)

\section{$2^{\text {nd }}$ Step: Coming up with an idea}

Students are expected to produce some ideas about the concepts related to the problem situation and to share their opinions with their group friends at this step. By asking various questions, it was tried to help students develop new ideas. The readiness levels of students have been adapted by asking questions and conducting discussions. Students shared their new ideas in their groups in a cooperative way. The purpose of this part is to help students to produce various ideas by asking interrogative and guiding questions about the information that students will utilize when creating ideas. The teacher rarely intervenes the process and tries to get students to find their own answers.

In figure 2 , the second step of the design process was presented. 


\section{LET'S THINK}

It is necessary for you to be able to explain the following situations to design your wind turbine properly. What kind of design are you expected to do?

.

What do you need to do before setting up the wind energy?

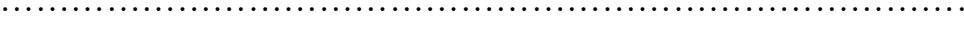

Does energy transformation occur in wind turbines? Please explain.

In your opinion, what are the parts of wind turbines? and how are their working principles?

You can do a research by using internet via tablets for the information you need also by using the answers of the above questions. Please list of the ideas stated in your group about the assigned task.

$\ldots .$.

$\ldots \ldots$

\section{Figure 2. The second step of the design process}

The samples regarding responses of the students given at this step can be given as in the following:

"We have to do a design that we can use wind energy. We will need a propeller for that." (Student 20)

"The region where we construct the wind turbine should definitely be windy." (Student 3)

"According to our research, windy energy is a kind of kinetic energy. In the system that we are going to set up, the kinetic energy should be converted to electric energy." (Student 37)

"The parts of the wind turbine are propeller, rotating parts, a tower carrying the engine part and the part which propeller is connected." (Student 23)

The examples regarding the ideas of the students can be given as in the following:

"We need to form the body with flat objects and bind the whole mechanism on it. In order to benefit more from the wind, we must make the propellers as large as possible." (Student 11)

"In order to prevent the turbine from flying due to the wind, the heaviest part must be the tower part. If we make a colourful turbine, we can draw the attention of other people, so that we can draw attention to the environmental problems." (Student 4)

\section{$3^{\text {rd }}$ Step: Planning and design fusion}

Students were asked to do a research and to write about their plans after finishing their research. Students were expected to specify their needs as a result of their research. At this step, they were asked to draw the shape of the product that they planned to do in order to activate their creativity. Students were set free as much as possible and they were not guided. It was expected from them to have a group discussion and to reach a conclusion. Students 
have not seen the tools and equipment at this point yet in order not to restrict their creativity.

The third step of the design process was presented in Figure 3.

Please, describe the best plan for your wind turbine.

$\ldots$

$\ldots \ldots$

......

Please, draw the shape of the wind turbine you are planning to do.

\section{Figure 3. The third step of the design process}

The plan that one of the groups made was given below.

"We are going to construct the propeller. Let's do it from carton. This propeller should not be too big. We need to think about both the cost and the tower because it cannot carry it. We have to connect the motor to the propeller. We are going to build the tower from thin wooden bars." (Group 2).

One of the sample drawings were given in Figure 4. 
Paper cup

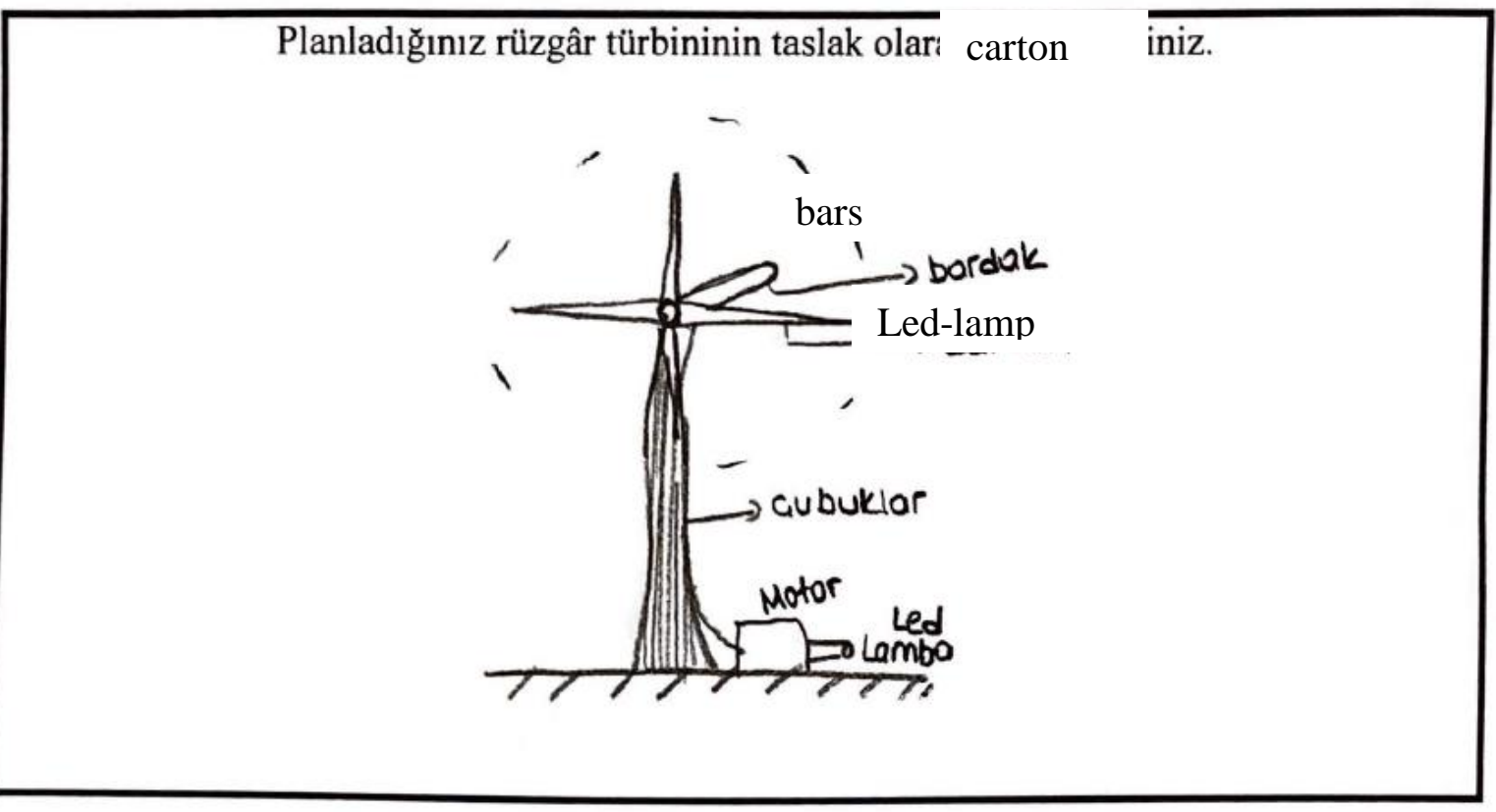

Figure 4. Sample drawing of students

Students were asked to make drawings so that they had opportunities to visualize their design and to be able to see the missing parts of their design easily. In addition to this, it would be easier to work on this as a group.

\section{$4^{\text {th }}$ Step: Making or synthesizing}

At this step, necessary tools and equipment which were listed under "Let's Do It" heading were given to the students. Students were expected to realize their design. At this step, cooperative work between students was ensured and students were encouraged to work like a scientist, an engineer, an artist, a mathematician or experts in technology. Various materials that are as colourful as possible and in different types were given to give students to help them to use their creativity and to activate arts dimension of STEAM. Students were set free and teachers did not intervene their design unless it was necessary.

The fourth step of the design process was presented in Figure 5. 


\section{-LET'S DO IT-}

The materials that you need to construct your wind turbine were given below.

- Paper cups

- Coloured ropes

-wooden thin bars

- cardboards in different colours

- Scissors

- Tape, glue

- Construction paper in different colours

- Coloured pencils and paints

- Ruler

- Motor

- Led-lamb

- Cords

- Tablets

Now you can do the frame of your turbine by using the following instruction which will help you in the construction of the wind turbine you plan.

- Please build the propeller of your turbine with the given cardboard given to you by using the colour you want. Ensure that the blades of the propeller are even by making necessary calculations.

- $\quad$ Build the tower part.

- $\quad$ Build the middle part which the propeller is connected to with the help of cardboards and paper cups.

- You can use the given materials as you wish while performing all the steps.

\section{Figure 5. The fourth step of the design process}

At this step, we should not commit any attempt to limit students' creativity Students are encouraged to think mathematically when building the propeller of the wind turbine. They were expected to think three-dimensionally, then to draw the propeller and finally to construct it by cutting it out of the paper. Teachers at this point should not tell students how to do it, but they should encourage their students to do research and to think about their topics. In this activity which was based on teaching science, students should be allowed to use their tablets whene ver they need to do research by using technology.

\section{$5^{\text {th }}$ Step: Testing}

The usability of the designs that students created freely and whether they work properly or not were tested. At this step, the designs created were only tested in groups and at the end of testing, the designs that were not working properly and that were not accepted as suitable were changed.

The fifth step of the design process was presented in Figure 6. 


\section{Now, you can construct your wind turbine as you wish and please give it a name.}

\section{YOUR WIND TURBINE IS READY :-}

Figure 6. The fifth step of the design process

Students named their wind turbines with the names like, hurricane, son of the wind, propeller of the rainbow. Teachers did not intervene the names given by the students and they were told that they could choose any name in their groups.

\section{$6^{\text {th }}$ Step: Evaluation}

At this step, students were expected to evaluate the products of all the other groups. Each group displayed their products and it was ensured for groups to be able to see the products of one another. Groups prepared presentation about their designs and explained why they chose to make such design. Some little notes were taken for each group about their designs on the board. The reasons why some groups did not achieve to get the expected results and why they came up with this failure were discussed. Whether the objectives were obtained or not was checked. The questions to be discussed were written under "Let's Answer" heading in order to prevent teachers and students from going beyond the planned teaching and they were distributed together with the worksheets. It was expanded to the new problem situations by using these questions.

The sixth step of the design process was presented in Figure 7. 


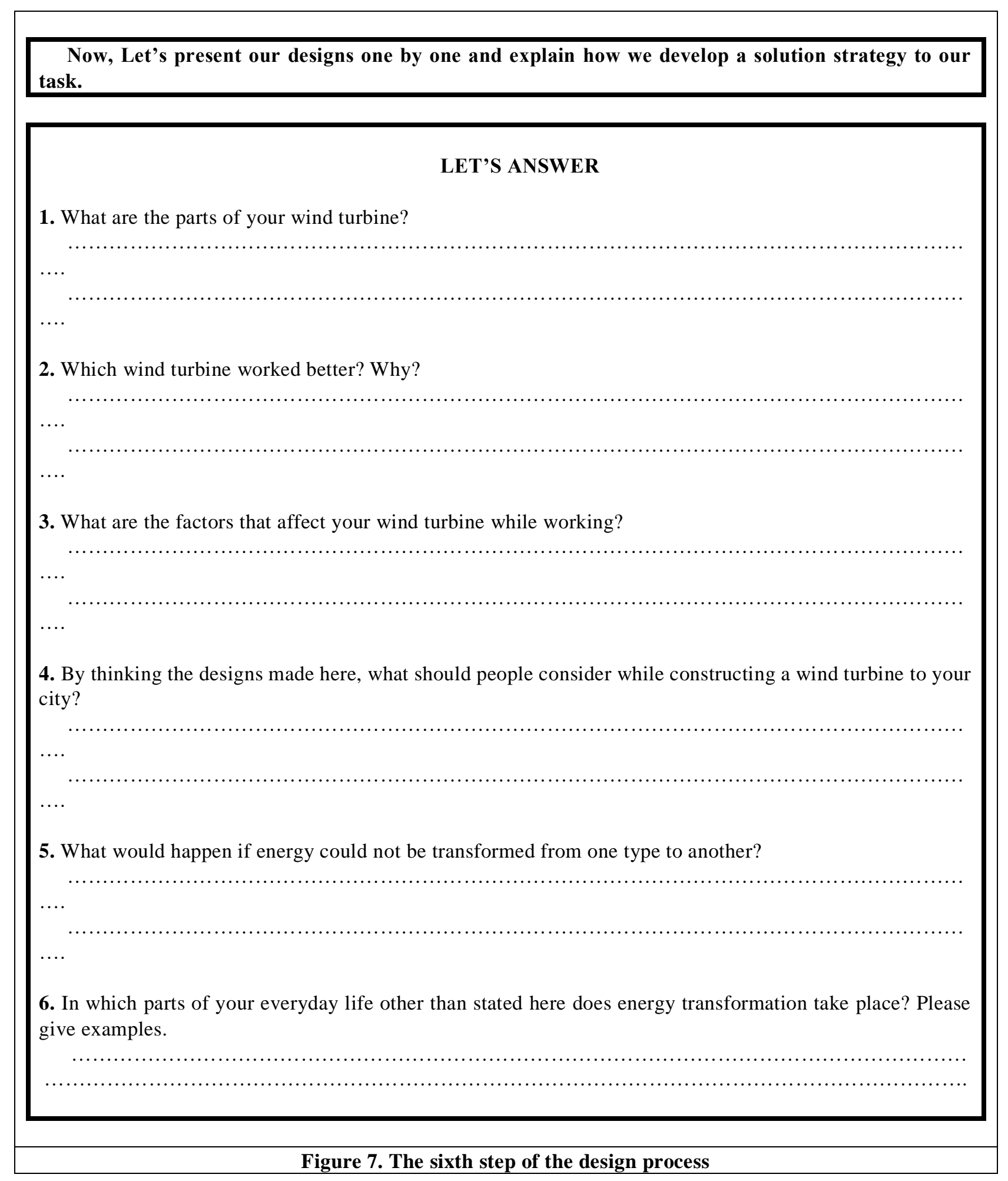

Students stated that they would place their wind turbine to a place near water resources and at the same time they could draw this water from the well by using kinetic energy. Setting students free as much as possible to let them use their creativity ensured them to use other ideas in their minds.

After group presentations, the answers of the questions used in the "Let's Answer" were searched in class discussions. The examples from the answers of the students were presented below. 
"There must be propellers. A body to which propeller is connected, a tower part and a part which produce electrical energy from the rotation move are the basic parts of a wind turbine" (Student 18).

"The hurricane worked better. Because it can stay in balance and it rotates more easily as it propellers are lighter." (Student14)

"It is maintaining balance, enabling propeller to rotate, arranging the weight and fixing it to the ground." (Student 2)

"First of all, we should check whether the place where we are going to set up the wind turbine receives enough wind or not. After that, we should determine the size of propeller that will be constructed by making necessary calculations" (Student 9)

"If energy did not transform into another form, we could not get the type of energy we wanted. Life would be very difficult. We could not get light from electrical energy and we could not have lighting." (Student 10)

"The electrical energy turns into heat energy in water heaters. When we throw a ball standing still above us, the potential energy becomes kinetic energy." (Student 12)

When implementing the activity, active participation of the students was ensured by engaging all of them into class discussions. The teacher was in the position of guiding and did not attend the process as possible. Students were encouraged to think freely. They were allowed to use the shapes and colours they want.

\section{Discussion and Conclusion}

In this study, a STEAM design activity was presented to be used as an example by the teachers. At the end of the activity it was concluded that all the students' groups displayed designs which can work. The conservation of energy is a subject which students mostly have misconceptions and it is because of the fact that the topic is abstract for the students (Yürümezoğlu, Ayaz \& Çökelez, 2009). Since students concretise this topic with a STEAM activity, it can be concluded at the end of the implementation that the activity developed within the scope of this study was effective, which is based on the observations of researchers and data collected from the students' worksheets. The misconceptions obtained from the open ended questions are as in the following; "The energy is consumed, becoming less or runs out of.", "None of the objects which does not move has any energy.", "Energy gets lost when transforming from one type to another.", "Energy is a force." It was determined that at the end of the study these misconceptions were corrected.

When literature is analysed, many studies analysing the perceptions of students and teachers on STEAM education and the implementation of STEAM education have been encountered (Choi, Lim \& Son, 2017; Gross \& Gross 2016; Jeong \& Kim 2015; Jho, Hong \& Song 2016; Kim \& Kim 2016; Oh, Lee, \& Kim, 2013). These studies stated the importance and necessity of STEAM education.

Similarly, Helvaci and Helvaci (2019) developed an E-STEM activity about environmental awareness. After the implementation with sixth grade students, it was concluded that students provided positive responses about the activity, its implementation and environmental awareness.

Gülhan and Şahin (2018) developed five activities about mirrors and light topic. The implementation was carried out with $7^{\text {th }}$ grade students. Observations were made and interviews were conducted during the study. It was concluded as a result of the study that students produced creative designs and students liked STEAM activities.

It is emphasized that STEAM applications are not only for students to have an interest in disciplines like sciencetechnology-engineering-arts-mathematics but also for them to learn these lessons with everyday connections (Yakman \& Lee, 2012). Also in this sample activity starting teaching by giving an example connected to everyday life may attract students' attention.

Park, Kim and Yoon (2015) confirmed that students realized convergent relationship between disciplines which are seemingly unrelated in their studies with STEAM education. It was aimed in this study to help students realize after STEAM implementation that science, technology, mathematics, arts and engineering are interrelated.

Students use some kind of measurement tools to be able to define that their designs are ready to work (ruler, thermometer etc.) (Bybee, 2011). The activities of STEAM education encourage to use mathematics while teaching science in this regard. In conclusion, the holistic structure of STEM education is modelling the interdisciplinary cooperation (Aslan-Tutak, Akaygün \& Tezsezen, 2017). STEAM education have included arts into this structure.

The objective in STEM education is to raise individuals like an engineer, scientist or technologist in the real life (Breiner, Harkness, Johnson \& Koehler, 2012). While developing activities, everyday life scenarios which make 
students feel like a mathematician, scientist, technology expert, engineer or artist while searching solution methods for the problems should be used.

In this study, materials, tools and equipment which teachers and students can easily find were used. In this way, it is believed that any science teacher can implement this activity easily.

\section{Limitations and Recommendations}

The basic limitation of this study is the fact that study group is really small. In addition to this, a quantitative comparison including control group was not conducted. For this reason, this study was presented as being an advisory study. Future studies should be carried out with a bigger study group to test the effect of STEAM activities on students' achievement. The following recommendations can be given about the teaching materials: researchers should base their studies on certain theoretical foundations while they are developing STEAM activities. In this study, Oh, Lee and Kim's (2013) creative design steps were utilized in developing STEAM activities. Besides, the activity which will be developed should aim to teach learning outcomes stated in the teaching program. In addition to this, it is advised to support activities with class discussions during teaching.

\section{KAYNAKLAR}

Aslan-Tutak, F., Akaygun, S., \& Tezsezen, S. (2017). Collaboratively learning to teach STEM: Change in participating pre-service teachers' awareness of STEM. Hacettepe University Journal of Education, 32(4), 794-816.

Breiner, J., Harkness, S., Johnson, C. C. \& Koehler, C. M. (2012). What Is STEM? A discussion about conceptions of STEM in education and partnerships. School Science and Mathematics, 112(1) 3-11.

Bybee, R. W. (2010). What is STEM education?. Science, 329(5995), 996-996.

Bybee, R. W. (2011). Scientific and engineering practices in K-12 classrooms: Understanding a framework for K-12 science education. The Science Teacher, 78(9), 34-40.

Choi, Y., Lim, Y., \& Son, D. (2017). A semantic network analysis on the recognition of STEAM by middle school students in South Korea. Eurasia Journal of Mathematics, Science and Technology Education, 13(10), 6457-6469.

Douglas, J., Iversen, E., \& Kalyandurg, C. (2004). Engineering in the K-12 classroom: An analysis of current practices and guidelines for the future. ASEE Engineering K12 Center.

Eroğlu, S., \& Bektaş, O. (2016). STEM eğitimi almış fen bilimleri öğretmenlerinin STEM temelli ders etkinlikleri hakkındaki görüşleri. Journal of Qualitative Research in Education, 4(3), 43-67.

Gonzalez, H. B., \& Kuenzi, J. J. (2012). Science, technology, engineering, and mathematics (STEM) education: A primer. Washington DC: Congressional Research Service, Library of Congress.

Gross, K., \& Gross, S. (2016). Transformation: Constructivism, design thinking, and elementary STEAM. Art Education, 69(6), $36-43$.

Guzey, S. S., Harwell, M., \& Moore, T. (2014). Development of an instrument to assess attitudes toward science, technology, engineering, and mathematics (STEM). School Science and Mathematics, 114(6), 271-279.

Gülhan, F., \& Şahin, F. (2018). Activity Implementation intended for STEAM (STEM+ Art) education: Mirrors and Light. Journal of Inquiry Based Activities, 8(2), 111-126.

Helvaci, S. C., \& Helvaci, İ. (2019). An interdisciplinary environmental education approach: determining the effects of E-STEM activity on environmental awareness. Universal Journal of Educational Research, 7(2), 337-346.

Jeong, S., \& Kim, H. (2014). "The effect of a climate change monitoring program on students' knowledge and perceptions of STEAM education in Korea. Eurasia Journal of Mathematics, Science \& Technology Education, 11(6), 1321-1338.

Jho, H., Hong, O., \& Song, J. (2016). An analysis of STEM/STEAM teacher education in Korea with a case study of two schools from a community of practice perspective. Eurasia Journal of Mathematics, Science \& Technology Education, 12(7), $1843-1862$.

Keefe, D. F., \& Laidlaw, D. H. (2013). Virtual reality data visualization for team-based STEAM education: Tools, methods, and lessons learned. In International Conference on Virtual, Augmented and Mixed Reality (pp. 179-187). Springer, Berlin, Heidelberg. 
Kim, B. H., \& Kim, J. (2016). Development and validation of evaluation indicators for teaching competency in STEAM education in Korea. Eurasia Journal of Mathematics, Science \& Technology Education, 12(7), 1909-1924.

Moomaw, S. (2013). Teaching STEM in the early years: Activities for integrating science, technology, engineering, and mathematics. Redleaf Press.

Oh, J., Lee, J., \& Kim, J. (2013). Development and Application of STEAM Based Education Program Using Scratch: Focus on 6th Graders' Science in Elementary School. In Multimedia and Ubiquitous Engineering, Lecture Notes in Electrical Engineering, edited by J. Park, et al., 493-501. Dordrecht: Springer.

Ozkan, G., \& Topsakal, U. U. (2017). Examining students' opinions about STEAM activities. Journal of Education and Training Studies, 5(9), 115-123.

Öner, A. T., \& Capraro, R. M. (2016). Is STEM academy designation synonymous with higher student achievement? Science and Education, 41(185), 1-17.

Park, N., \& Ko, Y. (2012). Computer Education's Teaching-Learning Methods Using Educational Programming Language Based on STEAM Education, In: Park, J., Zomaya, A., Yeo, S., et al (eds.), 7513, 320-327.

Park, Y. P., Kim, H. S., \& Yoon, M. B. (2015). The application of STEAM program utilizing Dodamsambong. Advanced Science and Technology Letters, 103, 114-119.

Ramaley, J. A. (2007). Facilitating change: Experience with the reform of STEM Education. Retrieved from: http://citeseerx.ist.psu.edu/viewdoc/summary?doi=10.1.1.526.8592 08.04.2019.

Sanders, M. (2009). STEM, STEM education, STEMmania. The Technology Teacher, 68(4), 20-26.

Rockland, R., Bloom, D. S., Carpinelli, J., Burr-Alexander, L., Hirsch, L. S. \& Kimmel, H. (2010). Advancing the "E" in K-12 STEM education. The Journal of Technology Studies, 36(1), 53-64.

Sağır, Ş. U., \& Kılıç, Z. (2013). The effect of argumentation based teaching on the understanding levels of primary school students about the nature of science. Hacettepe University Journal of Education, 44(44), 308-318.

Smith, J., \& Karr-Kidwell, P. J. (2000). The Interdisciplinary Curriculum: A Literary Review and a Manual for Administrators and Teachers. Retrieved from: https://eric.ed.gov/?id=ed443172. 08.04.2019.

Sousa, D. A., \& Pilecki, T. (2013). From STEM to STEAM: Using brain-compatible strategies to integrate the arts. Thousand Oaks, CA: Corwin Press.

Thomas, T. A., (2014). Elementary teachers' receptivity to integrated science, technology, engineering, and mathematics (STEM) education in the elementary grades. (Doctoral dissertation). Retrieved from Proquest. (3625770).

Wang, H. (2012). A New era of science education: science teachers ' perceptions and classroom practices of science, technology, engineering, and mathematics (STEM) integration. (Doctoral dissertation). Retrieved from Proquest. (3494678).

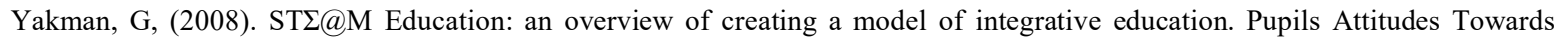
Technology. 2008 Annual Proceedings. Netherlands.

Yakman, G., \& Lee, H. (2012). Exploring the exemplary STEAM education in the U.S. as a practical educational framework for Korea. Journal of the Korean Association for Science Education, 32 (6), 1072-1086.

Yıldırım, A., \& Şimşek, H. (2008). Qualitative Research Methods in the Social Sciences (6th eds.). Ankara: Seçkin Publishing.

Yürümezoğlu, K., Ayaz, S., \& Çökelez, A. (2009). Grade 7-9 students' perceptions of energy and related concepts. Necatibey Faculty of Education Electronic Journal of Science and Mathematics Education, 3(2), 52-73. 


\title{
FEN EĞITIMINDE KULLANILABILECEK BİR STEAM ETKİNLİĞí
}

\author{
Gülbin ÖZKAN \\ Ünsal UMDU TOPSAKAL
}

\section{ÖZET}

STEAM eğitiminde fen, matematik, mühendislik, sanat ve teknoloji alanları tek tek öğretilmek yerine birbirine entegre edilerek bütüncül bir şekilde öğretilir. Ancak, öğrencilerin fen derslerindeki kavram, ilke ve olaylara ilişkin öğrenmelerin gerçekleşmesine yardımcı olan STEAM etkinliklerinin hazırlanması oldukça zor bir süreçtir. Bu çalışmada öğrenme-öğretme sürecinde yararlanılabilecek örnek olarak hazırlanmış bir STEAM etkinliğine yer verilmiştir. Etkinliğin tüm basamakları gerekli açıklamalar yapılarak sunulmuştur. Hazırlanan etkinlik, 37 katılımcıdan oluşan ortaokul yedinci sınıf öğrencilerine uygulanmıştır. Uygulama öncesinde ve sonrasında öğretimin etkililiğini belirlemek amacıyla üç adet açık uçlu sorudan oluşan bir soru formu uygulanmıştır. Uygulama sonucunda, geliştirilen etkinliğin öğrencilerin enerjinin korunumu konusunu öğrenmesinde etkili olduğu sonucuna ulaşılmış̧ır. Ayrıca etkinlik sonucunda tüm gruplar bir tasarım ortaya koymuşlardır. Bu nedenle öğrencilerin yanılgılarının yoğun olduğu enerjinin korunumu konusunda hazırlanan bu etkinliğin öğrencilerde anlamlı öğrenmeleri gerçekleştirebilecek faydalı bir ders etkinliği olacağı düşünülmektedir. Ayrıca kalabalık sınıflarda rahatça uygulanabilecek pratik bir öğretim tasarımı olarak da kullanılabilecektir.

Anahtar Kelimeler: STEM, STEAM, etkinlik, enerji, ortaokul öğrencileri 